\title{
Author Correction: Validation of miRNA prognostic power in hepatocellular carcinoma using expression data of independent datasets
}

Ádám Nagy ${ }^{1,2}$, András Lánczky ${ }^{1}$, Otília Menyhártt ${ }^{1,2}$ \& Balázs Győrffy $\varpi^{1,2}$

Correction to: Scientific Reports https://doi.org/10.1038/s41598-018-27521-y, published online 15 June 2018

The Acknowledgements section in this Article is incomplete.

“The study was supported by the NVKP_16-1-2016-0037 and the FIEK_16-1-2016-0005 grants of the National Research, Development and Innovation Office, Hungary."

should read:

“The study was supported by EFOP-3.6.3-VEKOP-16-2017-00009 grant and by the NVKP_16-1-2016-0037 and the FIEK_16-1-2016-0005 grants of the National Research, Development and Innovation Office, Hungary."

Open Access This article is licensed under a Creative Commons Attribution 4.0 International License, which permits use, sharing, adaptation, distribution and reproduction in any medium or format, as long as you give appropriate credit to the original author(s) and the source, provide a link to the Creative Commons license, and indicate if changes were made. The images or other third party material in this article are included in the article's Creative Commons license, unless indicated otherwise in a credit line to the material. If material is not included in the article's Creative Commons license and your intended use is not permitted by statutory regulation or exceeds the permitted use, you will need to obtain permission directly from the copyright holder. To view a copy of this license, visit http://creativecommons.org/licenses/by/4.0/.

(C) The Author(s) 2018 